\title{
Balinese Pop Music: An Industrialization Era
}

\author{
Ni Wayan Ardini \\ Department of Music, Institut Seni Indonesia Denpasar \\ email: wynardini@isi-dps.ac.id
}

\begin{abstract}
Balinese pop music appeared in 1970's but its industrialization refers to the development of the involved industries which began in 1990s. The industrialization is characterized by aspects of economy, technology, and new culture in music. All the aspects are related to each other. The economy can be seen in the growing capital in such a business. Technology is in the use of digital tecnology substituting the analog. New culture in music is shown in the more awareness of the Balinese people in enjoying Balinese pop songs. The Balinese are no longer shy singing such songs. This literature review uses techniques of qualitative data analysis. The result of the study shows that the industrialization consists of production, distribution, and consumption of the music. The production is created by the cultural power (musicians) and the capital power (capital owners). The distribution of the Balinese pop music in the current marketing is done by using the support of media power, particularly the electronic media, namely radio (since 1990s and even earlier), especially television (since 2002), in this case Bali TV. The production and distribution enables massive consumption in the Balinese society. The consumption is concerned with the existence of a new musical culture in the society. Although the industrialization tends to be capitalistic, Balinese artists or the musicians can earn their living through the Balinese pop songs. It is not a modern capitalism but postmodern one as the music relies on the existence of the Balinese society and their culture.
\end{abstract}

Keywords: Balinese pop music, industrialization, production, distribution, consumption.

\begin{abstract}
ABSTRAK
Musik pop Bali muncul pada tahun 1970-an tetapi industrialisasinya mengacu pada perkembangan industrial yang dimulai pada 1990-an. Industrialisasi ini dicirikan oleh aspek ekonomi, teknologi, dan budaya baru dalam musik. Semua aspek terkait satu sama lain. Perekonomian dapat dilihat dari pertumbuhan modal dalam bisnis semacam itu. Teknologi terlihat dalam penggunaan teknologi digital menggantikan yang analog. Budaya baru dalam musik ditampilkan dalam kesadaran yang lebih besar dari orang-orang Bali dalam menikmati lagu-lagu pop Bali. Orang Bali tidak lagi malu menyanyikan lagu-lagu seperti itu. Tinjauan kepustakaan ini menggunakan teknik analisis data kualitatif. Hasil penelitian menunjukkan bahwa industrialisasi musik pop Bali terdiri atas produksi, distribusi, dan konsumsi musik. Produksi diciptakan oleh
\end{abstract}


kekuatan budaya (musisi) dan kekuatan modal (pemilik modal). Distribusi musik pop Bali dalam pemasaran saat ini dilakukan dengan menggunakan dukungan kekuatan media, khususnya media elektronik, yaitu radio (sejak 1990-an dan bahkan lebih awal), khususnya televisi (sejak 2002), dalam hal ini Bali TV. Produksi dan distribusi tersebut memungkinkan konsumsi musik pop Bali besar-besaran dalam masyarakat Bali. Konsumsi berkaitan dengan keberadaan budaya musik baru di masyarakat. Meskipun industrialisasi ini cenderung bersifat kapitalistik, seniman Bali atau musisi dapat mencari nafkah melalui lagu-lagu pop Bali. Ini bukan kapitalisme modern tetapi postmodern, yakni sebagai musik yang bergantung pada keberadaan masyarakat Bali dan budaya mereka.

Kata kunci: music pop Bali, industrialisasi, produksi, distribusi, konsumsi.

\section{INTRODUCTION}

Industrialization of Balinese pop music (industrialisasi musik pop Bali) is the development of large scale businesses (e.g. music industries) of the Balinese pop music since the 1990s through its production, distribution, and consumption (Ardini, 2015, et al, <http://erepo.unud.ac.id/id/eprint/10610>; Ardini, 2017, $<$ http://ojs.pnb.ac.id/index.php/SOSHUM/article/view/598>; $\quad$ Ardini, $\quad 2016$, <https://ojs.unud.ac.id/index.php/ecs/article/view/18406>; Ardini, et al, 2018, $<$ http://ojs.pnb.ac.id/index.php/lJASTE/article/view/905>. Production (produksi) is constructing, planning, and creating product(s). Distribution (distribusi) includes promoting, selling, and distributing product(s). Consumption (konsumsi) includes the way how the consumer uses and enjoys product(s) after the process of transaction (buying).

The term "industrialization of music" (industrialisasi musik) is derived from Simon Frith's "The Industrialization of Music" (1988) and "The Industrialization of Popular Music" (2006). Music is a product of historical processes determined by the influence of technological change, system of economy, and new musical culture. According to Frith (Frith, 1988; Frith, 2006). Conceptually, music pop Bali is a blend between Balinese culture (language, pentatonic scale, musical instrument, costume, way of expression) and modern one (diatonic scale, musical instrument) (Ardini, 2015, et al, <http://erepo.unud.ac.id/id/eprint/10610>; Ardini, 2017, $<$ http://ojs.pnb.ac.id/index.php/SOSHUM/article/view/598>; $\quad$ Ardini, 2016 , 
$<$ https://ojs.unud.ac.id/index.php/ecs/article/view/18406>; Ardini, et al, 2018, $<$ http://ojs.pnb.ac.id/index.php/IJASTE/article/view/905>. It is not a traditional music nor modern one. In cultural studies, it can be classified into a postmodern music because of the blend itself.

The history of the Balinese pop music had been noted down since the first recording of Putra Dewata Band led by Anak Agung Made Cakra in 1970 with the album/song "Kusir Dokar" (The Horsecart Coachman) which in 1976 reached the peak of its popularity throughout Bali. In the 1980s such a music was modernized by Yong Sagita and several other musicians whose musical style was transformed into diatonic scales and themes of social criticism.

Because of the technological change, economic system, and new music culture in society as alluded by Frith $(1988 ; 2006)$, the Balinese pop music had been industrialized since 1990s through the increasing number of recording studios and musicians as well as the massive circulation of related products. This era was marked by the use of digital products, such as CDs (compact discs), together with cassette-tapes, in which a singer Widi Widiana with his themes of love and Chinese nuance come up as the Balinese pop music icon.

In the reform era (since 1998), the Balinese pop music politically had more space by the decentralization system through regional autonomy (in the 2000s) that supported the existence of the local art and culture, including the Balinese pop music itself. Even the music gained a better opportunity with the declaration of 2009 as Year of Creative Indonesia and even the creative economy/industry was legitimized by the presence of the Ministry of Tourism and Creative Economy in the United Indonesia Cabinet (KIB) II (SBY-Boediono). The Balinese pop music does not only contain social, and art and cultural aspects but also political. According to Street (1986: 23), politics of music is a combination among state policy, business practice, artistic choice, and response of the audience.

Based on the background above, the research problem is formulated into a question of "the forms of the industrialization of the Balinese pop music in Bali Province produced by the blend of the cultural, capital, and media power". It is expected that the result of the present study will be used to develop theoretically a 
vision of knowledge of cultural studies regarding the industrialization of pop culture in a provincial/local area, in this case the Balinese pop music. This study is also expected to provide scientific contribution to the development of cultural studies, musicology, art studies, and other related disciplines.

\section{THEORETICAL FRAMEWORK}

Pop(ular) music is a part of pop(ular) culture (budaya pop(uler)). Pop culture is very much liked by and originally comes from people but exploited by capitalism. Pop music (musik pop) is a kind of music belonging to pop culture which is massively produced because of the technological change, economic power, and new musical culture. Balinese pop music (musik pop Ball) is sourced from Balinese identity, especially its lyrics which use Balinese language.

Theory of Pop Culture (John Storey) notes that pop culture is as follows. First, being liked by a lot of people; Second, type of low work; Third, making people have fun; and being made for the people themselves; rest culture (residue); Fourth, being a "mass culture"; Fifth, being sourced from "the people"; Sixth, containing hegemony; and Seventh, being categorized as a postmodernist thought which oppose to the differentiation between high culture and pop culture (Storey, 2004: 10-25).

Theory of Pop Music (Theodor Adorno) views that standardization of pop music happens because, once established, a pattern of the music/lyrics will be exploited for commercial purpose (Adorno, 1948: 120). Pseudo-individualization is done to cover the standardization. Pop music creates a passive listener and act as social cement (Adorno in Storey, 2004: 155-156).

A musician Melly Goeslaw (2012) in her Balance indicates a number of critical success factors of the music industry products; they are song, arranger, producer, singer, label, promotion, and the fate. A society can be categorized into those who love music and have musical background or academic/private education, those who love music but have no musical background, those who always criticize (generally the media), real/genuine artist, mass people, and artist/celebrity community.

A number of pop musical concepts in this study are borrowed from Dieter Mack's Apresiasi Musik: Musik Populer (Musical Appreciation: Popular Music) 
(1995), such as pop music, which is different from popular music (e.g. a kind of music which is popular in a certain society). Pop music is really a part of popular music.

\section{METHOD}

This is a literature review about the process of production, distribution, and consumption of Balinese pop music starting from 1990's which is defined as an era of the industrialization of the music. Data are taken from journal articles, books, and research report). They were then analyzed by techniques of qualitative data analysis which are according to Miles and Hubberman (1992: 15-19) cover (1) data reduction, (2) data presentation, and (3) conclusion.

\section{RESULTS AND DISCUSSION}

As stated above, since the 1990s, the industrialization of the Balinese pop music, as part of the pop culture business, could be seen in the form of production, distribution, and consumption in Bali Province. There are three different powers working together in it. The cultural power in the form of aesthetic-musical talent/expertise in the Balinese pop musician as part of the Balinese people. The capital power is in the form of economic resource, namely the capital owners who processs the production of the Balinese pop music. The media power, which is the mass media, especially audio and audio-visual (television), serves to support the distribution.

The industrialization of the Balinese pop music, as stated by Frith (1988; 2006), is created through the development of technology, economic system, and new music culture in society. Production of the Balinese pop music is related to the use of digital technology which slowly replaces the analog one. Distribution is linked with the economic strategy of the capital owners, especially the use of television media. Consumption is concerned with the existence of a new musical culture in society.

Initiated by a singer Widi Widiana who acted as a pacemaker and even an icon, the Balinese pop music stars consists of Lolot, $[X X X]$, Bayu KW, Agung 
Wirasutha (now Agung Wiradana), Dek Ulik, Raka Sidan, and KIS Band. Various products are created, both recordings, shows/performances, and the other, which are essentially a standardization through a quasi-individualization. In the hands of the capital owners, the Balinese pop music is commercial practices where a lot of parties involve in earning their living. Anyhow, the musician is defeated in the system of profit share. According to Budiarto (2001), modern music is focused on market.

Not only in Bali, in a wider context, relating to the unbalance caused by the dominance of capitalism in the industrialization of music in Indonesia, a study done by Yuka Dian Narendra, Yunoke Rahma Andayani, and Ispawati Asri "Copyright, Panopticon dan ISA: Hak Cipta dan Kesadaran Palsu dalam Industri Musik Indonesia" (Copyright, Panopticon, and ISA: Copyright and False Consciousness in Music Industry in Indonesia) (2015) shows the unfair system of profit share between artist (musicians) and the industry (capital owners) in Indonesia. As the music business in Indonesia is too capitalistic, the musician is positioned under the control of capital owners.

Rudolf Dethu's Blantika Linimasa: Kaleidoskop Musik Non-trad Bali, Sejak Lahir, Tumbuh Kembang, Berdiri, Pingsan, Berdiri Lagi, dan Menolak Mati (Timeline Arena: Kaleidoscope of Balinese Non-trad Music, from Bearing, Growing, Standing, Fainting, Standing Again, and Rejecting to be Dead (2011) draws the history of Balinese nontraditional music, including the Balinese pop music, from the beginning of its emergence until the decade of 2000s.

Production in the industrialization of the Balinese pop music is created by the cultural power (musicians) and the capital power (capital owners). The musician provides musical input and the capital owners (producers/studio recording owners) then processes it into output (product). Production technology of the Balinese pop music evolves from analog system to digital one. Products such as cassette-tape emerge which are then slowly replaced by compact disc (VCD/DVD) (1990s), MP3, beside ringback tone (RBT) (2000s), bluetooth, and internet (online system) (2010s). Widi Widiana, Lolot, [XXX], Bayu KW, Agung Wirasutha, Dek Ulik, Raka Sidan, KIS Band become top artists/stars (artis bintang). Paradoxically, since 2000s, the 
technology of piracy (hijacking) also grew which caused problems and dynamics of the Balinese pop music in Bali.

Beside regular/conventional, there is a creative Balinese pop music but unfortunately its Balinese elements are less and less in tone scales, the use of lyrics in Balinese, presentation of music and musical instruments. Although created into various nuances (China, Banyuwangi/East Java, Central Java, Sunda, India, and West) and/or genre (rock, rap, reggae, disco), it is, according to Adorno's Theory of Pop Music (Storey, 2004: 155-156), pop music is a standardization which its distinction is just a pseudo-differentiation in order to make his or her products remain salable.

Producesr/recording studio owners as the center of power functions to distribute products of the Balinese pop music. Conventional distribution is done through direct distribution in which the producers/recording studio owners sell directly to actual and potential market. Indirect distribution is done through the cooperation with music shops, outlets, and stalls.

Distribution of the Balinese pop music in the current marketing is done by using the support of media power, particularly the electronic media, namely radio (since 1990s and even earlier) and television (since 2002). Radio and especially television promotes, disseminates, and even seduces and markets the related products. In addition to private radio stations such as AR, Gema Merdeka, Genta Swara Sakti, RRI Programa 4 Budaya, etc., Bali TV (established in 2002) played a very important role in the industrialization of the Balinese pop music until now. Bali TV is a symbol of development and preservation of the Balinese art and culture, including the Balinese pop music. Bali TV through "Klip Bali" (Balinese Video Clip), "Tembang Bali" (100\% lokal) (Balinese Song (100\% local)), and "Samatra Artis Bali" (Balinese Artist's Information), the Balinese pop music is loved by adolescents, adults, and the elderly, not only in urban areas but spreading to the rural villages in Bali. The role of other television stations for the industrialization of the Balinese pop music in Bali is not as important as Bali TV.

Production and distribution of the Balinese pop music enables ongoing massive consumption in the Balinese society. The production, distribution, and 
consumption in the industrialization of the Balinese pop music are not only linear but they affect each other. In fact, the consumption of the Balinese pop music also encourages the production and distribution due to the business instinct of the capital owners who work for the sake of the need and want of the market.

The industrialization of the Balinese pop music through standardization (as defined in Adorno's Theory of Pop Music) is enable to create a lot of consumers, especially the passive consumers, where the music becomes a social cement between themselves. Hall (in Storey, 2006: 14) categorizes such consumers into hegemonized/dominated listeners. But, however, result of this study showed that, in addition to the passive, there are active consumers, who according to Hall, are negotiated listeners and oppositional audiences. Oppositional listeners are classified into expert listeners although their amount is limited.

The consumers of the Balinese pop music are mostly the low and middle socio-economic groups in Bali. Such a condition affects the way they buy, consume, and enjoy the Balinese pop music. Since the hijacking (piracy) is not successfully finished yet, they choose to buy related products (illegal ones) recklessly than the original which price is relatively much more expensive.

\section{CLOSING}

The Balinese pop music, in the context of its industrialization, has started since the 1990s when it got massive production, distribution, and consumption in Bali due to the development of technology, economy, and a new musical culture in the society. Cultural power (musicians/aesthetic-musical) and the capital power (producers/recording studio owners) work together for the production. For its distribution, the capital owners more cooperate with the media, such as radio and especially television. Bali TV plays a very important role so that the Balinese pop music is really loved.

So many members of the Balinese people/society who are scattered in Bali Province become the market and object of consumption of the various Balinese pop music products. The passive consumers and other market types arise. In contrast, 
the consumption also affects the production and distribution, resulting in the continuous consumption which is economically beneficial for the capital owners.

Inevitably, with its interests in gaining the economic profit, capitalism, is the dominant ideology of the Balinese pop music. There are some other ideologies working in it, they are popism, politics of the local culture, and culturalism. The greatness of the capitalism is its ability to build awareness (knowledge) that the Balinese pop music is not for the sake of gaining the capital interest, instead for developing and preserving the Balinese art and culture.

Above all, the goodness of the industrialization of the Balinese pop music is its position as postmodern capitalism which relies on the existence of the Balinese society and their culture.

\section{REFERENCES}

Adorno, Theodor Wiesendgrund. 1948. Philosophy of Modern Music. London: Sheed \& Ward.

Ardini, Ni Wayan. 2016. "Industrialisasi Musik Pop Bali: Ideologi, Kepentingan, dan Praktiknya", dissertation, Doctorate Programs in Cultural Studies, Universitas Udayana, Denpasar <http://erepo.unud.ac.id/id/eprint/10610>. Date accessed: 14 may 2018.

Ardini, Ni Wayan. 2017. "Keberagaman Irama dan Nuansa Musikal dalam Industrialisasi Musik Pop Bali", Soshum : Jurnal Sosial dan Humaniora, [S.I.], v. 7, n. 2, p. 264-272, oct. ISSN 2580-5622. Available at: <http://ojs.pnb.ac.id/index.php/SOSHUM/article/view/598>. Date accessed: 04 july 2018.

Ardini, Ni Wayan; Wirawan, AA Bagus; Suarka, I Nyoman; Sugiartha, I Gede Arya. 2015. "Power of Media in Industrialization of Balinese Pop Music". E-Journal of Cultural Studies, [S.I.], v. 8, n. 4. ISSN 2338-2449. Available at: <https://ojs.unud.ac.id/index.php/ecs/article/view/18406>. Date accessed: 14 may 2018.

Ardini, Ni Wayan; Astuti, Ni Nyoman; Darmayuda, I Komang; Armoni, Luh Eka; Sumerjana, Ketut. 2018. "Issues in the Relationships among Balinese Pop Music, Tourists, and the Tourism Industry", International Journal of Applied Sciences in Tourism and Events, [S.I.], v. 2, n. 1, p. 80, june. ISSN 2580- 
5592. Available at: <http://ojs.pnb.ac.id/index.php/lJASTE/article/view/905>. Date accessed: 04 july 2018.

Budiarto, C. Teguh. 2001. Musik Moderen dan Ideologi Pasar. Yogyakarta: Tarawang Press.

Dethu, Rudolf. 2011. Blantika Linimasa: Kaleidoskop Musik Non-trad Bali, Sejak Lahir, Tumbuh Kembang, Berdiri, Pingsan, Berdiri Lagi, dan Menolak Mati. Denpasar: Matamera Book.

Frith, Simon. 1988. Music for Pleasure. New York: Routledge.

. 2006. "The Industrialization of Popular Music" dalam Andy Bennet, Barry Shank, and Jason Toynbee (eds.) The Popular Music Studies Reader. London: Routledge.

Goeslaw, Melly. 2012. Balance. Jakarta: Komunitas Bambu.

Mack, Dieter. 1995. Apresiasi Musik: Musik Populer. Yogyakarta: Yayasan Pustaka Nusatama. . 2004. Musik Kontemporer dan Persoalan Interkultural. -: Arti.

Miles, Matthew B; Michael A. Huberman. 1992. Analisis Data Kualitatif. Jakarta: UII Press.

Narendra, Yuka Dian, Yunoke Rahma Andayani, and Ispawati Asri. 2009. "Copyright, Panopticon dan ISA: Hak Cipta dan Kesadaran Palsu dalam Industri Musik Indonesia", Marcommers Jurnal Marketing Communication \& Advertising, Vol. 1, No. 1, October, p. 92-107.

Storey, John. 2004. Teori Budaya dan Budaya Populer: Memetakan Lanskap Cultural Studies. Yogyakarta: CV. Qalam.

2006. Cultural Studies dan Kajian Budaya Pop: Pengantar Komprehensif Teori dan Metode. Yogyakarta: Jalasutra. 